\title{
PERLINDUNGAN HUKUM TERHADAP PENCIPTA MUSIK SEBAGAI SUARA LATAR DI YOUTUBE
}

\author{
Komang Ariadarma Suputra, Ida Ayu Putu Widiati, Ni Made Sukaryati Karma \\ Fakultas Hukum Universitas Warmadewa, Denpasar - Bali, Indonesia
}

\begin{abstract}
Abstrak
Penggunaan musik sebagai suara latar video saat ini marak terjadi di media sosial Youtube. Hal ini tidak lepas dari keuntungan moral dan ekonomi yang didapat penggunanya melalui fitur-fitur yang ditawarkan Youtube. Oleh karena itu, sebagai negara hukum, Indonesia sudah sepantasnya memberikan perlindungan hukum terhadap Pencipta Musik yang karyanya digunakan. Tujuan penelitian ini yaitu menganalisis perlindungan hukum terhadap Pencipta Musik sebagai suara latar di Youtube dan mengetahui sanksi yang diberikan terhadap channel Youtube yang melakukan pelanggaran hak cipta. Metode penelitian yang digunakan adalah penelitian hukum normatif dengan pendekatan perundang-undangan dan konseptual. Hasil penelitian menunjukkan bahwa musik merupakan hasil ekspresi manusia yang terdapat unsur keindahan di dalamnya. Sehingga, perlu adanya perlindungan hukum yang diberikan terhadap Penciptanya. Perlindungan hukum bersifat preventif, ialah dirumuskannya hak eksklusif Pencipta Musik ke dalam Pasal 5 dan Pasal 9 UU No. 28 Tahun 2014 tentang Hak Cipta dan secara represif, Pencipta Musik dapat memperjuangkan haknya yang telah dilanggar melalui jalur pengadilan dan di luar pengadilan. Adapun sanksi terhadap pelanggaran hak cipta musik sebagai suara latar video di Youtube, yaitu sanksi berupa ganti rugi atas kerugian yang telah ditimbulkan sebagaimana diatur dalam Pasal 99 UU No. 28 Tahun 2014 tentang Hak Cipta. Sanksi pidana diatur dalam Pasal 113 ayat (4) UU No. 28 Tahun 2014 tentang Hak Cipta berupa pidana penjara maksimum 10 tahun dan/atau pidana denda maksimum Rp. 4.000.000.000.00.
\end{abstract}

Kata Kunci: Pencipta Musik; Perlindungan Hukum; Suara Latar

\begin{abstract}
The use of music as video background sound is currently rife on social media Youtube. This is inseparable from the moral and economic benefits that users get through the features offered by Youtube. Therefore, as a state of law, Indonesia should appropriately provide legal protection for Music Creators whose works are used. The purpose of this study is to analyze the legal protection of Music Creators as a background voice on Youtube and find out the sanctions imposed on Youtube channels that commit copyright infringement. The research method used is normative legal research with statutory and conceptual approaches. The results showed that music is the result of human expression that has an element of beauty in it. Thus, the need for legal protection is given to the Creator. Legal protection is preventive, namely the formulation of the exclusive right of a Music Creator to Article 5 and Article 9 of Law no. 28 of 2014 concerning Copyright and repressively, the Music Creator can fight for his rights that have been violated through the courts and outside the court. As for the sanctions against violations of music copyright as the background sound of videos on Youtube, namely sanctions in the form of compensation for damages that have been caused as stipulated in Article 99 of Law No. 28 of 2014 concerning Copyright. Criminal sanctions are regulated in Article 113 paragraph (4) of Law no. 28 of 2014 concerning Copyright in the form of a maximum imprisonment of 10 years and / or a maximum fine of $R p$. 4,000,000,000.00.
\end{abstract}

Keywords: Music Creator; Legal Protection; Soundtrack

\section{PENDAHULUAN}

Keinginan untuk melindungi dan mempertahankan hak atas suatu hasil karya dari ekspresi manusia, pada akhirnya telah mendorong terlahirnya konsep yang saat ini dikenal dengan Hak Kekayaan Intelektual (HKI). Hak yang didapat setelah ide/gagasan manusia diwujudkan ke dalam bentuk nyata (Banindro, 2015:13). Karya yang dihasilkan dari pemikiran manusia ini, merupakan objek yang diatur dalam HKI. Konsep HKI yang dahulu bertujuan untuk memberikan perlindungan dan pengakuan hak 
terhadap Pencipta atas hasil karyanya, kini telah berkembang menjadi suatu alat yang dimanfaatkan oleh Pencipta untuk mengeksploitasi hasil ciptaannya demi mendapatkan keuntungan ekonomi.

Hak Cipta sendiri merupakan salah satu produk HKI yang mana didalamnya mengatur tentang hak eksklusif yang terdiri hak ekonomi (economic rights) dan hak moral (moral rights) dari Pencipta. Hak ekonomi tersebut memberi kekuasaan bagi Pencipta untuk mengeksploitasi karya ciptanya sendiri yang bertujuan untuk mendapatkan keuntungan ekonomi dari pihak lain yang ingin memanfaatkan karya ciptanya tersebut. Kebutuhan terhadap ketentuan perundang-undangan untuk mellindungi Pencipta dari segala bentuk pelanggaran, pada akhirnya menjadi pendorong bagi pemerintah mengeluarkan peraturan perundang-undangan mengenai Hak Cipta yaitu Undang-Undang Nomor 28 Tahun 2014 tentang Hak Cipta (UUHC).

Salah satu hasil dari kreativitas manusia yang dilindungi oleh hak cipta adalah musik. Manusia menciptakan musik dengan tujuan untuk memenuhi kebutuhan akan hiburan dalam hidupnya dan musik juga dapat menjadi media bagi manusia untuk mengekspresikan apa yang sedang ia rasakan sehingga dapat membangkitkan gairah dan spirit hidup. Seiring perkembangan zaman, musik tidak hanya bermanfaat sebagai hiburan, tetapi juga memiliki nilai ekonomi yang dapat menghasilkan keuntungan berupa materi.

Perkembangan teknologi yang semakin canggih, mengakibatkan penggunaan musik untuk kepentingan pribadi dengan tujuan tertentu menjadi sulit dikendalikan, yang berdampak merugikan terhadap Pencipta. Salah satu pelanggaran hak cipta yang marak terjadi saat ini berupa penggunaan musik sebagai suara latar di Youtube. Para pihak yang mengunggah video atau yang sering disebut content creator/Youtuber biasanya memasukan musik ke dalam videonya sebagai suara latar guna memperkuat suasana yang tercipta saat menonton video tersebut. Suara latar sendiri juga biasa digunakan oleh Youtuber guna memperindah videonya, yang bertujuan menarik minat penonton untuk melihat video yang diunggahnya. Belum jelasnya UUHC dalam memberikan definisi musik pada pasal 40 ayat (1) huruf d yang menyatakan bahwa "lagu dan/atau musik dengan atau tanpa teks" memberikan celah yang dapat dimanfaatkan oleh pihak-pihak yang tidak bertanggung jawab untuk membenarkan tindakan mereka atas penggunaan musik secara ilegal sehingga dapat menjadi penghalang dalam usaha perlindungan hukum bagi Pencipta Musik. Terkait dengan penelitian saat ini telah banyak diluncurkan oleh para ahli seperti Albar, Rohaini2, \& Rusmawati, (2018); Rahma \& Nurhayati, (2020); Salindeho, (2017) membahas tentang perlindungan tentang hak cipta. Namun objek penelitian saat ini berbeda dengan penelitian sebelumnya. Oleh karena itu, berdasarkan latar belakang permasalahan yang telah diuraikan di atas, maka penelitian ini bertujuan untuk mengetahui perlindungan hukum terhadap Pencipta Musik sebagai suara latar di Youtube dan mengetahui sanksi yang diberikan terhadap channel Youtube yang melakukan pelanggaran hak cipta musik.

\section{METODE PENELITIAN}

Tipe penelitian yang digunakan dalam penelitian ini adalah penelitian hukum normatif yaitu dengan melakukan pengkajian berdasarkan bahan-bahan hukum dari literatur dan merupakan suatu proses untuk menemukan aturan hukum, prinsip- prinsip hukum, maupun doktrin-doktrin hukum guna menjawab isu hukum yang dihadapi demi menghasilkan argumentasi, teori dan konsep baru dalam menyelesaikan masalah yang dihadapi. Pendekatan masalah yang digunakan adalah Pendekatan Perundang-undangan (Statute Approach) dan Pendekatan Konseptual (Conceptual Approach).

Adapun sumber bahan hukum yang digunakan yakni bersumber dari penelitian, kepustakaan, yaitu berupa: Bahan hukum primer, yaitu bahan-bahan hukum yang mengikat, berupa undang-undang, yakni: Undang-Undang Dasar Negara Republik Indonesia Tahun 1945 (UUD NRI 1945), Kitab Undang-Undang Hukum Perdata (KUHPerdata), Undang-Undang No. 28 Tahun 2014 tentang Hak Cipta (UUHC), Undang-Undang No. 11 Tahun 2008 tentang Informasi dan Transaksi Elektronik (UU ITE). Bahan hukum sekunder yaitu bahan-bahan hukum yang diperoleh dari pengkajian kepustakaan (Library Research) yaitu dengan membaca buku hukum, jurnal-jurnal hukum, surat kabar, dan internet yang berkaitan dengan Perlindungan Hukum Terhadap Hak Cipta Musik sebagai permasalahan yang dibahas.

Untuk memperoleh bahan-bahan hukum primer dan sekunder penulis menggunakan penelitian dengan memakai teknik pengumpulan bahan dengan menggunakan teknik pencatatan, membaca buku-buku, peraturan perundang- undanganserta literatur lainnya yang berkaitan dengan permasalahan yang penulis bahas. Semua bahan-bahan yang sudah di dapat dalam penulisan ini, 
selanjutnya disusun dan dianalisis secara sistematis dengan menggunakan argumentasi hukum berdasarkan logika hukum deduktif dan hasilnya disajikan secara deskriptif analisis.

\section{HASIL PENELITIAN DAN PEMBAHASAN Perlindungan Hukum terhadap Pencipta Musik}

Maraknya penggunaan karya cipta seperti pembajakan, pencurian ide atau tidak memberikan kompensasi atas penggunaan Ciptaan telah mencedarai hak eksklusif dari Pencipta. Dalam filsafat teori hukum alam hal tersebut tidaklah dibenarkan dimana dari beberapa isinya merumuskan bahwa jangan mencuri atau jangan mengambil yang bukan hakmu. Sehingga masyarakat merasa perlu mendapatkan perlindungan secara hukum untuk melindungi hak mereka dari segala pelanggaran. Salah satu undang-undang di Indonesia yang berlaku saat ini dan dibentuk guna melindungi HKI, yaitu Undang-Undang No. 28 Tahun 2014 tentang Hak Cipta.

Undang-Undang ini dibentuk dengan tujuan untuk melindungi hasil Ciptaan manusia dibidang seni, sastra dan ilmu pengetahuan. Subjek dari perlindungan hukum terhadap hak cipta ialah Pencipta yang menghasilkan suatu karya cipta. Menurut Pasal 1 angka 2 dan 28 UUHC, Pencipta adalah orang perseorangan maupun badan hukum baik sendiri ataupun bersama-sama yang menghasilkan suatu karya cipta yang bersifat baru, orisinil dan beda dari pada yang lain.

Konsep tentang perlindungan hukum yang tercantum dalam UUHC, menjelaskan tentang ciptaan yang dilindungi, salah satunya musik (Pasal 40 ayat (1) hurud d). Menurut Suhastjarja dalam (Widyaswara \& Tigita, 2018) musik adalah perwujudan dari isi hati, ide atau gagasan manusia yang terbentuk dari unsur nada- nada, ritme dan harmoni yang disusun dan di gabung menjadi satu, sehingga dapat dimengerti dan juga dapat dinikmati oleh orang-orang yang mendengarnya. Perlindungan hukum timbul dan diberikan terhadap subyek hukum dalam bentuk perangkat hukum, bersifat preventif maupun yang bersifat refresif.

Dalam hak cipta perlindungan hukum ditujukan terhadap hak eksklusif yang dimiliki oleh Pencipta yang menghasilkan suatu karya, sehingga yang mendapat perlindungan hukum dari objek ciptaan musik adalah Pencipta Musik sendiri. Penulis mencoba merumuskan yang dimaksud Pencipta Musik adalah subjek hukum yang menghasilkan suatu karya di mana dalam karyanya tersebut terkandung unsur melodi, syair atau lirik, irama, tempo, dinamika, harmoni, timbre, tangga nada yang disusun sedemikian rupa menjadi satu kesatuan yang utuh.

Menurut Pasal 4 UUHC hak eksklusif Pencipta Musik yang dilindungi terdiri atas hak moral dan hak ekonomi. Hak moral melekat pada diri Pencipta atau pelaku yang tidak dapat dihilangkan atau dihapus tanpa alasan apa pun, walaupun hak cipta atau hak cipta telah dialihkan. Lebih lanjut, diatur dalam Pasal 5 ayat (1) UUHC mengenai hak moral Pencipta Musik dapat dibagi menjadi dua, yaitu (Hidayah, 2017:40) hak untuk diakui sebagai Pencipta (authorship right atau paternity right), bahwa identitas Pencipta harus dicantumkan dalam karya seorang Pencipta dan Hak keutuhan karya (the right to protect the integrity of the work), yaitu melarang tindakan perubahan terhadap ciptaan yang berpotensi merusak reputasi Pencipta.

Masa berlaku Hak moral menurut Pasal 5 ayat (2) UUHC berlaku tanpa batas waktu dan tidak dapat dialihkan selama Pencipta masih hidup, tetapi pelaksanaan hak tersebut dapat dialihkan dengan wasiat atau sebab lainsetelah Pencipta meninggal dunia.Berdasarkan Pasal 9 UUHC, bahwa Hak ekonomi melarang pihak lain menggunakan karya cipta untuk tujuan komersil tanpa izin Pencipta.

Pada kenyataannya, sering kali ditemui pelanggaran terhadap hak eksklusif Pencipta Musik dalam kehidupan sehari-hari. Pemerintah melalui aturan UUHC memberikan pilihan bagi Pencipta Musik untuk menyelesaikan sengketa melalui jalur pengadilan dan di liuar pengadilan. Berikut mekanisme penyelesaian bagi Pencipta yang ingin mempertahankan haknya (Hidayah, 2017):

a. Gugatan Perdata diatur dalam Pasal 98 UUHC, Pencipta Musik berhak untuk mengajukan gugatan ganti rugi kepada pengadilan niaga atas pelanggaran hak ciptaannya.

b. Tuntutan Pidana yang diatur di dalam Pasal 112-118 UUHC, Pengajuan gugatan perdata tetap bisa dilakukan besama tuntutan pidana. Sebelum dilakukan uapaya pidana, harus dilakukan upaya mediasi terlebih dahulu sebelum tuntutan pidana dilakukan (Pasal 95 ayat 4 UUHC).

c. Penyelesaian sengketa yang dilakukan di luar pengadilan dapat dilakukan dalam bentuk negosiasi, mediasi, konsiliasi, dan cara lain yang dipilih oleh para pihak sesuai dengan undangundang yang berlaku (Pasal 95 UUHC). 
Salah satu media sosial yang saat ini sering digunakan adalah Youtube. Youtube menjadi wadah untuk mengekspresikan diri bagi penggunannya dengan cara mengunggah video yang mereka buat. Bahkan kini, Youtube juga dapat digunakan sebagai sumber untuk mendapatkan uang. Youtuber dapat mengirim permintaan kepada phak Youtube agar blog Youtube mereka dapat dilakukan monetisasi. Permintaan monetisasi bertujuan agar video yang diunggah oleh Content Creator/Youtuber dapat dipasang iklan demi mendapat keuntungan materi. Hal ini tentu memacu semangat dari pemilik blog Youtube untuk membuat video yang lebih menarik lagi. Salah satu caranya dengan memasukan unsur musik sebagai suara latar ke dalam video mereka. Unsur musik dimasukan agar penonton ikut merasakan suasana yang terjadi saat menonton video. Sehingga penonton tanpa sadar ikut larut dalam momen yang sedang mereka saksikan di video tersebut.

Penggunaan musik demi kepentingan pribadi saat ini sedang marak terjadi. Pencipta Musik yang sudah bersusah payah mengorbankan tenaga dan pikiran untuk menghasilkan suatu karya cipta, tidak mendapatkan kompensasi apapun atas penggunaan musiknya. Untuk mengantisipasi suatu pelanggaran terhadap Hak Cipta, Pencipta Musik dan Pihak Youtube dapat membuat suatu perjanjian tertulis/lisensi yang mengatur mengenai penggunaan musik tersebut (Pasal 80 ayat (1) UUHC).

Melalui Lisensi, Pemegang Hak Cipta dapat membuat sebuah kesepakatan dengan Youtube yang mengatur mengenai hak dan kewajiban masing-masing pihak dalam hal pengelolaan karya cipta musik dalam video yang dibuat oleh Content Creator/Youtuber yang di unggah di situs Youtube. Melalui perjanjian yang diadakan, kedua belah pihak dapat menuangkan apa saja keinginan mereka atas penggunaan musik, termasuk mengatur mengenai sanksi dan cara yang dapat digunakan untuk menyelesaikan sengketa yang mungkin terjadi diantara kedua belah pihak dikemudian hari. Dengan adanya lisensi, Youtube dapat menggunakan musik dengan aman di situs mereka melalui cara yang benar dan Pemegang Hak Cipta pun mendapatkan kompensasi atas pemanfaatan musik mereka di situs Youtube.

Dalam hal membuat perjanjian, kedua belah pihak harus memperhatikan syarat-syarat yang diatur dalam Pasal 1320 KUHPerdata agar perjanjian yang mereka buat sah secara hukum dan mengikat bagi kedua belah pihak, adapun syaratnya yaitu kesepakatan, cakap secara hokum, suatu hal tertentudan, kausa yang halal (Matompo \& Harun, 2017:108).

Akibat dari perjanjian yang dibuat antara Pemegang Hak Cipta dan Youtube, kita dapat melihat dalam video yang berisi musik, nantinya akan ditampilkan informasi tentang lagu yang terdapat di dalam video creator di kotak deskripsi. Sebagai ganti atas eksploitasi Ciptaan, Pencipta Musik berhak mendapatkan Royaltiyang ditentukan oleh kesepakatan para pihak berdasarkan kelaziman praktik yang berlaku dan memenuhi harus unsur keadilan (Pasal 80 ayat (5) UUHC). Perjanjian Lisensi wajib didaftarkan pada Ditjen HKI agar memiliki akibat hukum terhadap pihak ketiga, yakni pembeli barang cipta maupun pesaing usaha (Supramono, 2010:53). Perjanjian lisensi yang tidak dicatatkan tidak memiliki akibat hukum bagi pihak ketiga, jika ada masalah penerima lisensi tidak dianggap keberadaannya di mata hukum, sehingga berakibat fatal bagi penerima lisensi, karena bisa dituding sebagai pelanggar hak cipta dan harus bertanggung jawab sendiri atas segala kerugian yang terjadi (Pasal 83 ayat (1) dan (3) UUHC).

Liberalisasi ekonomi adalah reformasi ekonomi yang dilakukan demi menciptakan ekonomi yang berbasis pasar (Wikipedia). Hal ini mengakibatkan transisi industrial dalam masyarakat Indonesia, artinya masyarakat Indonesia yang dahulunya merupakan masyarakat agraris yang berbudaya sosial tradisional saat ini sedang dalam proses perubahan menuju masyarakat yang individual modern. Perubahan ini berdampak pada kurangnya pemahaman mengenai konsep hak cipta yang sebelumnya belum pernah dikenal oleh masyarakat tradisional, mereka berpendapat bahwa karya cipta tidak hanya semata-mata berorientasi pada materi, tapi juga mempunyai nilai sosial dan keagamaan. Hal ini secara tidak langsung telah memberi ruang untuk melegalkan segala pelanggaran hak cipta.

Pelanggaran hak cipta pada dasarnya terjadi pada hak moral dan hak ekonomi yang dimiliki oleh Pencipta. Jika kita melihat Pasal 9 ayat (3) UUHC, seseorang dikatakan melakukan pelanggaran hak cipta jika memenuhi dengan unsur: 1. Orang, yang dimaksud orang dalam UUHC merupakan yaitu: orang perseorangan atau badan hukum (Pasal 1 angka 28 UUHC). 2. Tanpa izin Pemegang Hak Cipta, yaitu Izin adalah pernyataan mengabulkan/membolehkan (KBBI). Jadi tanpa izin, ialah seseorang yang menggunakan suatu ciptaan tanpa memiliki pernyataan mengabulkan/disetujui dari Pemegang Hak Cipta, 3. Penggandaan dan/atau penggunaan ciptaan, yaitu penggandaan adalah suatu 
proses, cara yang digunakan untuk memperbanyak suatu ciptaan (KBBI). Penggunaan berarti proses, cara, perbuatan menggunakan sesuatu; pemakaian (KBBI), dan 4. Secara Komersil, menurut Pasal 1 angka 24 UUHC, berarti "memperoleh keuntungan ekonomi dari berbagai sumber atau berbayar." Jadi, segala penggunaan ciptaan demi kepentingan ekonomi tanpa adanya persetujuan dari Pemegang Hak Cipta dapat diartikan sebagai sebuah pelanggaran hak cipta.

Youtube merupakan media sosial yang memberikan banyak manfaat bagi penggunanya. Seperti menjadi wadah untuk mengekspresikan diri, tempat untuk bertukar informasi, bahkan menjadi tempat berbisnis yang dapat memberikan keuntungan tidak sedikit. Namun, dibalik manfaat yang diberikan, situs ini juga memiliki sisi negatif yang merugikan bagi beberapa pihak, khususnya di bidang HKI.

California-Ultra Records, sebuah perusahaan label rekaman, menggugat oknum yang menggunakan musik-musik produksi mereka secara sembarangan di Youtube sebagai backsound video. Michelle Phan, bintang Youtube, salah satu yang digugat karena melakukan hal itu kepada artis-artis perusahaan tersebut. Menurut perusahaan, Phan telah mengambil musik dari artis mereka tanpa izin dan mendapatkan keuntungan dari hal itu (melalui iklan video di Youtube). Label rekaman itu juga mengklaim telah memperingatkan Phan beberapa kali, tetapi dia tidak menghiraukannya.

Berdasarkan kasus, di atas Penulis mencoba untuk mengaitkannya dengan ketentuan yang terdapat dalam Pasal 9 ayat (3) UUHC, yang mengatur mengenai unsur-unsur dari pelanggaran hak cipta: 1. Unsur orang, dalam kasus di atas ialah Michelle Phan sebagai orang perseorangan yang mempunyai channel dan tampil dalam video yang diunggahnya di Youtube. 2. Unsur tanpa izin Pemegang Hak Cipta, pernyataan yang dikeluarkan pihak perusahaan Ultra Records, dapat diketahui bahwa Michelle Phan belum memperoleh izin untuk penggunaan karya cipta yang diproduksi pihak Ultra Records. 3. Unsur penggandaan dan/atau penggunaan, musik yang dimasukan sebagai suara latar ke dalam video merupakan suatu proses, cara, perbuatan yang telah dilakukan untuk memadukan musik dengan video yang awalnya terpisah sehingga menjadi satu. 4. Unsur komersil, tindakan Phan yang memasang iklan di dalam video yang berisi unsur musik tersebut merupakan satu langkah yang dibuat untuk mendapatkan keuntungan ekonomi.

\section{Sanksi Terhadap Pelanggaran Hak Cipta Musik Sebagi Suara Latar Video Di Youtube}

Banyaknya pelanggaran hak cipta yang terjadi menuntut pemerintah untuk cepat tanggap menyelesaikan persoalan tersebut. Salah satu cara yang dilakukan ialah dengan pemberian sanksi terhadap pelanggar hak cipta. Menurut Sudikno Mertokusumo dalam (Ali, 2015), sanksi merupakan reaksi, akibat atau konsekuensi pelanggaran kaidah sosial sanksi yang diberikan kepada Pelanggar hak cipta memiliki bobot yang berbeda-beda disesuaikan dengan bentuk dan jenis pelanggaran. Berdasarkan Pasal 113 UUHC sanksi yang dapat diberikan, sebagai berikut.

1. Pelanggaran hak cipta berupa menyewakan ciptaan demi mendapat keuntungan materi tanpa izin dapat dikenakan sanksi berupa pidana penjara maksimum 1 tahun dan/atau maksimum denda Rp. 100.000.000.00.

2. Pelanggaran hak cipta berupa penerjemahan, pengadaptasian, pengaransemenan atau pentransformasian, pertunjukan ciptaan dan/atau komunikasi suatu ciptaan dapat dikenakan pidana penjara maksimum 3 tahun dan/atau pidana denda maksimum Rp. 500.000.000.00.

3. Pelanggaran hak cipta berupa penerbitan, penggandaan, pendistribusian dan/atau pengumuman suatu ciptaan dapat dikenakan sanksi pidana penjara maksimum 4 tahun dan/atau pidana denda maksimum Rp. 1.000.000.000.00.

4. Pelanggaran hak cipta yang memenuhi unsur pasal 9 ayat (3) UUHC dikenakan sanksi berupa pidana penjara maksimum 10 tahun dan/atau denda maksimum Rp. 4.000.000.000.00.

Selain sanksi pidana, pelanggar hak cipta juga dapat dikenakan sanksi perdata berupa ganti rugi atas pelanggaran yang dilakukan. Gugatan ganti rugi berupa permintaan untuk menyerahkan seluruh atau sebagian penghasilan yang diperoleh si pelanggar atas penggunaan ciptaan tersebut (Pasal 99 UUHC).

\section{SIMPULAN DAN SARAN}

\section{Simpulan}

Berdasarkan uraian di atas, maka dapat ditarik beberapa simpulan, yaitu 1) Perlindungan hukum terhadap Pencipta Musik sebagai suara latar di Youtube dibagi menjadi dua bentuk, yakni perlindungan hukum secara preventif dan represif. Perlindungan hukum secara preventif, yakni 
dengan dirumuskannya hak eksklusif yang dimiliki oleh Pencipta Musik ke dalam UU No. 28 Tahun 2014 tentang Hak Cipta. Dalam Pasal 5 ayat (1) UU No. 28 Tahun 2014 tentang Hak Cipta diatur hak moral Pencipta Musik yang mengharuskan Pemilik Channel Youtube untuk mencantumkan identitas Pencipta Musik dan melarang tindakan perubahan terhadap ciptaan yang berpotensi merusak reputasi Pencipta Musik dan hak ekonomi melarang pemilik channel Youtube menggunakan karya cipta untuk tujuan komersil dalam bentuk apapun tanpa izin Pencipta Musik (Pasal 9 UU No. 28 Tahun 2014 tentang Hak Cipta). Sedangkan, perlindungan hukum bersifat represif, penyelesaian sengketa melalui jalur pengadilan dan di luar pengadilan bagi Pencipta Musik yang merasa haknya telah dilanggar. Melalui jalur pengadilan, Pencipta Musik dapat mengajukan gugatan perdata ke Pengadilan Niaga atas pelanggaran hak cipta yang dilakukan oleh pemilik channel Youtube sebagaimana diatur dalam Pasal 98 UU No. 28 Tahun 2014 tentang Hak Cipta. Melalui jalur di luar pengadilan/Alternative Dispute Resolution (ADR) dapat dilakukan dalam bentuk negosiasi, mediasi, konsiliasi, dan cara lain yang dipilih oleh para pihak yang bersengketa sesuai dengan undang-undang yang berlaku (Pasal 95 UU No. 28 Tahun 2014 tentang Hak Cipta). 2) Sanksi yang diberikan terhadap channel Youtube yang melakukan pelanggaran hak cipta musik, berupa sanksi perdata dan sanksi pidana. Secara perdata pemilik channel Youtube dapat dikenakan sanksi berupa ganti rugi atas kerugian yang telah ditimbulkan sebagaimana diatur dalam Pasal 99 UU No. 28 Tahun 2014 tentang Hak Cipta. Sedangkan, sanksi pidana yang dapat dikenakan terhadap pemilik channel Youtube diatur dalam Pasal 113 ayat (4) UU No. 28 Tahun 2014 tentang Hak Cipta berupa pidana penjara maksimum 10 tahun dan/atau pidana denda maksimum Rp. 4.000.000.000.00.

\section{Saran}

Dari pemaparan hasil analisis di atas, peneliti merekomendasikan secara khusus kepada pemerintah agar melakukan sosialisasi lebih giat lagi mengenai pemahaman tentang hak cipta dalam masyarakat, mengingat transisi masyarakat yang terjadi menjadi salah satu penyebab maraknya pelanggaran hak cipta di Indonesia karena masih banyak masyarakat yang belum paham bahwa suatu karya cipta adalah hal yang eksklusif dilindungi oleh hukum. Selanjutnya, dalam penggunaan suatu karya cipta diharapkan masyarakat agar meminta izin terlebih dahulu terhadap Pemegang Hak Cipta. Izin merupakan suatu hal yang penting dalam bidang hak cipta. Selain untuk menghindari terjadinya suatu pelanggaran hak cipta, izin dapat ditujukan sebagai bentuk penghargaan bagi Pencipta yang telah mengorbankan tenaga dan waktunya untuk dapat menghasilkan suatu karya cipta.

\section{DAFTAR PUSTAKA}

Albar, A. F., Rohaini2, \& Rusmawati, D. E. (2018). Perlindungan Hukum Penggunaan Musik sebagai Latar dalam Youtube Menurut Undang-Undang Hak Cipta. Pactum Law Journal, 1(04), 321335.

Ali, A. (2015). Menguak Tabir Hukum (2nd ed.). Jakarta: Kencana.

Banindro, B. S. (2015). Implementasi Hak Kekayaan Intelektual (Hak Cipta, Merek, Paten, Desain Industri) Seni Rupa, Kriya dan Desain. Yogyakarta: BP ISI.

Hidayah, K. (2017). Hukum Hak Kekayaan Intelektual. Malang: Setara Press.

Matompo, O. S., \& Harun, N. (2017). Pengantar Hukum Perdata,. Malang: Setara Press.

Rahma, H., \& Nurhayati, Y. (2020). Legalitas Cover Song Yang Diunggah Ke Akun Youtube. AlAdl : Jurnal Hukum, 12(1), 77-88.

Salindeho, C. C. (2017). Perlindungan Musik dan Lagu di Era Teknologi Internet dalam Perspektif Undang- Undang Hak Cipta Indonesia. Lex et Societatis, v(5), 150-158.

Supramono, G. (2010). Hak Cipta dan Aspek-Aspek Hukumnya. Jakarta: Rineka Cipta.

Widyaswara, \& Tigita. (2018). Menulis Lagu Dari Hati. Jakarta: Widyaswara.

Undang-Undang Dasar Negara Republik Indonesia Tahun 1945. Kitab Undang-Undang Hukum Perdata.

Undang-Undang Nomor 28 Tahun 2014 Tentang Hak Cipta. Lembaran Negara Republik Indonesia Tahun 2014 Nomor 266. Tambahan Lembaran Negara Republik Indonesia Nomor 5599.

Undang-Undang Nomor 11 Tahun 2008 Tentang Informasi dan Transaksi Elektronik.

Lembaran Negara Republik Indonesia Tahun 2008 Nomor 58. Tambahan

Lembaran Negara Republik Indonesia Nomor 4843. 